\title{
Facilitating Competency and Skill Development Through Video Assignment
}

\author{
Vijaya Eligar $^{1}$, Rajeshwari M Banakar ${ }^{2}$ \\ ${ }^{1,2}$ ECE Department KLE Technological University, BVB Campus, Hubli, India \\ 1'vijayaeligar@bvb.edu,'banakar@bvb.edu
}

\begin{abstract}
Competency and skill development are the two requirements during the course learning duration. Constructivism, objectivism and conceptualism are three theories used as a base for knowledge enhancement. Opportunities provided to the students in the courses to express themselves should increase along with the acquisition of in-depth technical knowledge. To motivate and engage students to develop intrinsic skills like, self determination, self monitor and reasoning are supported by well known theory of constructivism and objectivism. Planning an atmosphere to do a task is related to objectivism. Learner's ability to increase competence is known as constructivism which depends on the attitudes of the learner. Students' competency and communication skill can be enhanced by various active learning activities like coding assignments and video assignments. These learning activities provide suitable environment and motivation for competency development. The benefits of various assignments tabulations indicate that project assignments are the most beneficial because of learning pace and handson experience. Video assignments are excellent for communication skill development with lots of creativity involved with digital gadgets.
\end{abstract}

\footnotetext{
Vijaya Eligar

ECE Department KLE Technological University,

BVB Campus, Hubli, India

vijayaeligar@bvb.edu
}

Course content learning through video assignment is nominal. The respondent's reflection of $92.6 \%$ for creativity in video assignment and $72 \%$ for course content competency suggests that in video assignment students enjoy the course learning.

Keywords : competency, communication skills, video assignment, motivation, creativity

\section{Introduction}

Currently education scenario is different in the "digital age" with students possessing smart phones. The student is engaged with the smart phones with one or the other "app". Course teaching to the 21 st century students should be

designed, to ensure relevant competency, keeping in mind the smart gadget usage. Along with competency the student should be given an opportunity for skill development Competency and skill are like the two faces of the same coin. They should always go handin-hand. 


\section{A. Competency}

In [1] the authors categorize the competency related to information into five types, namely, technical, communication, social, academic and organizational. The "digital age" is influential in the conclusive decision, that information competency cohesively binds the five competencies. It is also recommended that information competency is one of the goals of teaching. An essential capability of the teacher lies in designing the course delivering and assignment that facilitate competency development in the students.

In [2][3][4] the author Harter address the famous competence motivation theory, subsequently, known as Harter's theory. The theory throws sufficient light on the origin of competence theory. It is stated that motivation increases multifold when an individual masters a skill successfully. It is evident from the Harter's theory that competence and skill are interrelated with each other. The studies are done for a classroom continuity and observation.

In [5] C.K. Prahlad and Hamel discuss the core competency related to the growth of companies and corporate sectors. It is stated that competency building is challenging and different. Applying the competency architecture in education sector, competence learning environments should be knitted together with a goal to enhance motivation and support information competency development. A profound strategy in skill development allows a student to nurture personality development. In [6] Robert White presents that the reason for healthy and enterprising behaviour, requires a suitable ambience where the competence and skill can be enhanced. Competence is the effective involvement of an individual to get hold strongly on a particular skill.

In [7][8] the authors describe competence and commitment in the context of improving leadership style. It is stated that with right direction and encouragement the team members can develop good competence. A mention of different expertise like problem solving and communication skill associated with competence is a curious signpost to apply to education research. In specific, the competence of the students can be enriched increasing the motivational level to perform a given work. Typical experiments are performed to differentiate intrinsic and extrinsic motivation. Competence was observed in 24 students for 3 sets of experiments to solve a soma cube puzzle.
It is evident from the results presented that intrinsic motivation is the key driving force to develop problem solving skill to remain competent.

In [9] the authors indicate that competence increases intrinsic motivation and skill development is more pronounced, in a right environment. A directional effort from the instructor plays a significant role in the personality development of an individual. Another intrinsic feature associated for a good success factor, by the authors is the self determination theory. The context of discussion is the role of a coach in athletics.

All the literature reviews mentioned above give a clear view that competence is to be facilitated in the right environment. The case studies are related to education, leadership in corporate, problem solving skill and sports. The common salient feature projected in all these is skill development. Competence requires suitable extrinsic support to obtain intrinsic motivation. In today's context, competence theory continues to be renewed and applied in a number of applications leading to a broad perspective.

\section{B. Communication skill}

The two competencies mentioned above are related to the course subject matter to demonstrate the competency to identify the software components in ECC230 in Data structures. It is evident from the above discussed literature review that if a student is given an opportunity to a specific task intrinsic motivation increases. A sincere effort is made to enhance the competence through skill development in particular communication skill development.

In [14][10] the authors discuss the importance of contextualization, which is simply the knowledge of the contents related to subject. Whenever the context is clearly known, it influences the interpretation of communicative message. The response in terms of verbal communication has great impact on the audience attention if the context is put across strongly.

In [11][12] the authors discuss what is cognitive learning? Cognitive learning is the intrinsic ability of an individual to interpret the situation by observation. It is interestingly demonstrated that an individual's self-monitoring ability to synthesis and evaluate the messages is crucial and it plays a significant role. The theory of constitution which explores functioned communication competence is described. The three 
requirements of communication are proficiency in language, ability to express correctly and descriptively, ability to comprehend, reflect and reason out to regulate information. Forming detailed, explanatory description and contextualizing the information, systematic presentation of information, engaging in depth to describe the accurate information and generating different views on the same information are the requirements of a good communicator.

In [13][15] the author focuses carefully on attitudes of an individual. Attitude formation is a process of reaction that an individual experiences. Attitude formation is the response to mental map formed as a reaction toward a person, object event or social context. Use of knowledge and its interpretation plays an important role in attitude formation and is always a change factor, which can be introduced as information by the course instructor. This provides relevant opportunity to increase competency. The authors discuss the reality of providing atmosphere to the students, to enhance competence. Providing an atmosphere to perform a task is related to objectivism. Learner's ability to promote competence is known as constructivism. Both are essential for students overall development. Collectively looking at both competence and skill (communication) development, in the above mentioned literature reviews it is evident that a focused direction towards a particular task gives fruitful results.

In [7][12][8] it is conveyed that the competence can be increased by offering educational opportunities to the students in the form of training, social interpretation and professional interpretation. As a conclusive remark the problem solving competency, subject competency and personality development competency are the expected traits of a successful student and talented student. This will in-turn increases intrinsic motivation and the student learning increases.

In [9][11] interestingly the authors relate two intrinsic knowledge of any individual. One is in the situation related to competence development. The other is in the context related to theory of skill development namely conceptualism. The first one is the self-determination theory and the second one is the self-monitoring ability. These two always increase the attention memory of an individual. It is sufficiently evidenced that the key factor to promote both competence and skill development is by providing each student a supporting, ambience and opportunity to do a task.

In [16][17][18] the author's discuss the impact of digital age on students. The forecast presented is reality in just a decade after the authors work. Almost all the students are with smart phones, tabs and iphones with access to Wi-Fi and network services. The teacher can leverage the benefit of the tech. Savvy student's mindset to design suitable course assignments. The author analyses the mindset of students who are brought up with gadgets with them. They support field base project and activity based learning environment to improve the competency and skills of the students.

In [19][20] the author strongly favours active learning environment in classroom environment and assignments which reflect learning by doing depth and detail about the things that are most useful to them. They choose what is important to them. The authors state that $94 \%$ of the students surveyed (age 12-17) use internet. Hence the students coming to College are used to the technology gadgets. The findings indicate that the present generation students spend more time in getting knowledge.

In [21][22][23] the authors discuss about the values and habits of the digital age students. It is pointed out that students are self reliant and creative. They are able to focus quickly and are adaptable to the changes. New pedagogical classroom techniques are to be followed by the teachers. The authors describe that through video assignments students are provided with an opportunity to engage in learning. The students improve their communication skills and also provide background knowledge of the subject matter. The usefulness of active learning is described. Students are interested in active learning and they look forward to utilize their digital age skills. Video assignments were educational and some technical learning did happen to students. The involvement of the student is more in video assignments. Students individually take the responsibility of acquiring knowledge.

In [24][25] the authors describe their experience of giving video assignments and give a finding that comparing written assignments and video assignments, the statistical results show that through video assignments understanding is better. Students are more engaged and also more disciplined in context learning. Typical writing assignments in engineering 
streams are also discussed. It is explained that the student should be trained to communicate both orally and written. They should gain the ability to share knowledge.

In [26][27] the authors discuss how presentation skills can be improved. When students are speaking to a group of or learned audience, they are anxious and hesitant. It is suggested that many opportunities should be created in the course delivery to improve communication skills. Video assignments are one of the pedagogy techniques that can be used in the classroom environment

\section{To Motivate And Engage Students}

From the literature survey conducted the following inferences can be summarized. Students competency can be enhanced through various active learning activities. Motivating and engaging students, giving creative assignments was beneficial Students should acquire message interception skill and subject competency to apply the knowledge approximately. Mental mapping ability is the philosophy of knowledge and cognitive task analysis is through real time environment to develop skills. Constructivism, objectivism and conceptualism are three theories of knowledge enhancement.

The interpretation of skill development to engage students is presented in the Table 1 along with theories to motivate and engage students. Video assignments were chosen as the type of the assignments with total four assignments during the semester, $40 \%$ of the internal assessment was for assignment where the students were allowed to demonstrate the knowledge in a creative way.

In the context of this paper competence is related to learning Data structures in C using typical video assignment. The performance indicators for the course are:

口 Ability to identify the software components (pointers, stacks, queues, lists)

口 Ability to identify design principles for the development of software systems.

A typical requirement in this is proper planning by the course instructor which is described as teachers' reflections, since this is scaled for 150 students. Student identification should be written on a paper or typed and this should be projected in the beginning.
Any written material presentation should be only 4-6 lines on one sheet with large font size. Creativity, compilation, confidence and concepts should be evaluated. Video CD submission should be with student identification and proper video play format.

The course instructor should accord due attention to the students effort. View and evaluate them sincerely, students feel happy that they are keenly observed.

\section{Table 1. To Motivate And Engage Students}

\begin{tabular}{|l|l|l|l|}
\hline $\begin{array}{l}\text { Knowledge } \\
\text { theory }\end{array}$ & Constructivism & Objectivism & Conceptualism \\
\hline Applies to & $\begin{array}{l}\text { Philosophy of } \\
\text { understanding }\end{array}$ & $\begin{array}{l}\text { Cognitive } \\
\text { task analysis }\end{array}$ & $\begin{array}{l}\text { Content } \\
\text { knowledge }\end{array}$ \\
\hline Process & Mental mapping & $\begin{array}{l}\text { Real time } \\
\text { environment }\end{array}$ & $\begin{array}{l}\text { Descriptive } \\
\text { analysis }\end{array}$ \\
\hline Outcome & Skill development & $\begin{array}{l}\text { Subject } \\
\text { competency }\end{array}$ & Interpretation \\
\hline Builds & $\begin{array}{l}\text { Message } \\
\text { interception skill }\end{array}$ & $\begin{array}{l}\text { Application } \\
\text { scenario }\end{array}$ & Depth processing \\
\hline $\begin{array}{l}\text { Intrinsic } \\
\text { Skills } \\
\text { (Life long } \\
\text { learning) }\end{array}$ & $\begin{array}{l}\text { Self } \\
\text { determination, } \\
\text { self monitor }\end{array}$ & $\begin{array}{l}\text { Knowledge } \\
\text { Deployment }\end{array}$ & Reasoning \\
\hline
\end{tabular}

\section{Benefits Of Different Types Of Assignment: An Overview}

A consolidated overview is presented in Table 2 to bring out the benefit and difference of each type of assignment. The three types of assignments chosen to reflect the difference are

口 Written Assignment

૫ VideoAssignment

૫ ProjectAssignment

The parameters chosen for comparison are assistance, background preparation times suitable for, interest by students, technical knowhow, creativity, stress on design principles etc. From the salient features it is found that written assignments is the best for content learning by the students. Written assignments provide good knowledge of the subjects. Self reflection is better in written assignments.

Memory retention is very good in written assignments. Video assignments are suitable in digital age, experience is remembered more than content. Conceptualization is excellent in video assignment, both technology and concept learning happens. Media exposure is more and communication skill improves. For students having stage fear, communication apprehension, video assignments are best suited. 
Project assignments are in a team for undergraduates, where practical exposure is excellent in this. Lots of excitement prevails in the project assignments, students experience some "wow" moments. Good pace of learning is available to the students. Technical exposure is the best here. Project assignments cater to technological advancement, pedagogical learning content knowledge and also practical knowledge.

Other assignments are class test, surprise quiz, scheduled quizzes, design projects, lab test, and open book test.

Table 2. An Overview Of Different Types Of Assignments

\begin{tabular}{|c|c|c|c|}
\hline & $\begin{array}{l}\text { Written } \\
\text { Assignment }\end{array}$ & $\begin{array}{l}\text { Video } \\
\text { Assignment }\end{array}$ & $\begin{array}{l}\text { Project } \\
\text { Assignment }\end{array}$ \\
\hline \multirow[t]{3}{*}{$\begin{array}{l}\text { Knowledge } \\
\text { type }\end{array}$} & $\begin{array}{l}\text { Pedagogy } \\
\text { content }\end{array}$ & Pedagogy content & $\begin{array}{l}\text { Pedagogy } \\
\text { content }\end{array}$ \\
\hline & & Technology & Technology \\
\hline & & & $\begin{array}{l}\text { Practical } \\
\text { Hands on }\end{array}$ \\
\hline Duration & 1-week & 15 days & $1-2$ months \\
\hline Assistance & $\begin{array}{l}\text { May take } \\
\text { others help }\end{array}$ & Self help & team \\
\hline $\begin{array}{l}\text { Back ground } \\
\text { Preparation } \\
\text { time } \\
\end{array}$ & Nominal & More & Most \\
\hline Suitable & $\begin{array}{l}\text { Problem } \\
\text { solving } \\
\text { discussion }\end{array}$ & $\begin{array}{l}\text { Concept } \\
\text { understanding }\end{array}$ & $\begin{array}{l}\text { Practical } \\
\text { deployment } \\
\text { program } \\
\text { execution }\end{array}$ \\
\hline Knowledge & Excellent & Enjoyable & Excitement \\
\hline Creativity & Nominal & Excellent & Ok \\
\hline $\begin{array}{l}\text { Memory } \\
\text { retention }\end{array}$ & Content & Experience & Technique \\
\hline Skill & $\begin{array}{l}\text { Problem } \\
\text { solving }\end{array}$ & Visualization & $\begin{array}{l}\text { Solution } \\
\text { provider }\end{array}$ \\
\hline $\begin{array}{l}\text { Design } \\
\text { principles }\end{array}$ & $\begin{array}{l}\text { Very good } \\
\text { knowledge }\end{array}$ & $\begin{array}{l}\text { Less knowledge } \\
\text { gain }\end{array}$ & $\begin{array}{l}\text { Hands-on } \\
\text { experience }\end{array}$ \\
\hline $\begin{array}{l}\text { When to give } \\
\text { grading }\end{array}$ & $\begin{array}{l}\text { To improve } \\
\text { content ability }\end{array}$ & $\begin{array}{l}\text { Improve concepts } \\
\text { and } \\
\text { communication }\end{array}$ & $\begin{array}{l}\text { To improve } \\
\text { practical } \\
\text { experience }\end{array}$ \\
\hline $\begin{array}{l}\text { Instructors } \\
\text { Work load }\end{array}$ & Nominal & More & Nominal \\
\hline
\end{tabular}

\section{Skill Based Learning}

Pedagogical technique was implemented for the subject Data structures in C. The objective was to enhance competency and improve communication skills. The basic issues that arouse before the course commencement were as follows. How to provide suitable opportunity to the students to increase competence and also improve communication skill? Should it be reflected as an assignment evaluation which carried $40 \%$ weightage in continuous internal evaluation (CIE)? Which type of assignment will the students do with interest in this digital age? Is the type of assignment scalable to two classes, with a total strength of 150 students? What will be the assessment workload on the two course instructors?

Based on these reflections, video assignments were also planned for the Data structures Course. There were totally four reviews conducted for the students. Coding in C language was done as follows: Each class of 75 students was divided into 25 batches with 3 students per batch. Each batch was given different application database to develop. The first review was on File programming for the chosen database application. The second review was on stacks and queue operations for the same application. The third review was on Linked list for the chosen application. The fourth review was on Trees for the same application.

Apart from coding assignment, video assignment was given for the second review to improve the communication and presentation skills of the students. The soft copy of the software developed was collected for each batch. Each student also submitted the video assignment in a CD. The feedback was collected for each class. Out of 150 students 135 students responded to the feedback questionnaire. The respondents answered questions relating to two major descriptions namely communication skill and competency development.

Communication skill was the independent variable with the dependent variable attributes namely creativity, topic knowledge, stage fear and video shooting. Competency was the independent variable with the dependent variable attributes content competency, applying skill and topic written document. The feedback questions are shown in Table 3.

Table 3. Feedback Questions

\begin{tabular}{|l|l|}
\hline & Communication Skill \\
\hline 1. & $\begin{array}{l}\text { Was it interesting and creative assignment to improve your } \\
\text { communication skills? }\end{array}$ \\
\hline 2. & $\begin{array}{l}\text { How helpful the video assignment was to enhance knowledge of the } \\
\text { topic given? }\end{array}$ \\
\hline 3. & Was the video assignment effective to overcome stage fear? \\
\hline 4. & $\begin{array}{l}\text { Could you formulate suitable analogies to communicate the concepts } \\
\text { (examples, pictures, objects)? }\end{array}$ \\
\hline 5. & $\begin{array}{l}\text { Did the video assignment help you to know the fundamentals of the } \\
\text { video shooting? }\end{array}$ \\
\hline & Competency development \\
\hline 6. & $\begin{array}{l}\text { Did the video assignments help you to identify software components } \\
\text { (stacks, Queue, Linked List and Trees)? }\end{array}$ \\
\hline 7. & $\begin{array}{l}\text { Did the video assignment help you to identify software components } \\
\text { and use in an application? }\end{array}$ \\
\hline 8. & $\begin{array}{l}\text { Did the video assignment motivate you to prepare a written } \\
\text { document in a logical sequence before presentation? }\end{array}$ \\
\hline
\end{tabular}




\section{Respondents Reflections and Discussions}

This section presents the result analysis of the research work carried out. The Likert scale [28] used for feedback had a rating of 4, 3, 2, 1 for every question. The information collected is ordinal data, which is relative in nature. There are four steps on the Likert scale with a logical sense of rating as Strongly agree (4) to fairly agree (1). The point of neutrality is not taken on the scale. The Likert scale developed depends on the choice of the investigator. The questions also vary for different investigators. In [24] it is stated that video assignments are better than written assignments for the students learning. In our approach a more detailed study has been conducted for skill development and competency development.

The results show a high acceptance of video assignment for the attribute, "creativity" score of 92.6 $\%$. The next two accepted attributes by the respondents are topic knowledge improvement and stage fear reduction, with a response of around $88 \%$. These percentage numbers are obtained from the frequency distribution bar depicted in Fig. 1. The Likert scale rating for Q1 is on creativity. The total number of students is 135 . The respondents answer for scale 4 and 3 were 72 and 53 . The sum is 125 out of 135. (92.6\%). The improvement in creativity is evident from this result.

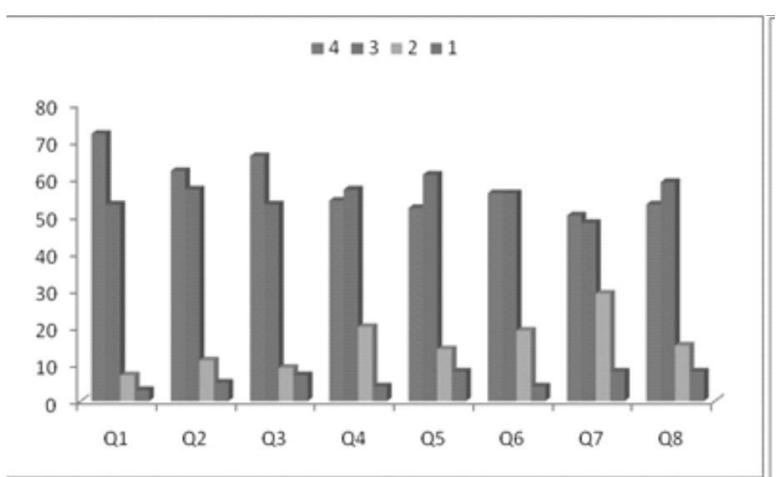

Fig. 1. Feedback Statistics (Q1-Q5 Communication Skill, Q6-Q8 Course Competency)

The lowest score the respondents have given is for the attribute applying skills (to identify software components and use in an application). The reason for this is, concentration for video assignment, coding and conceptual understanding at the same time is difficult for the students. There is a need to explore how these attributes can be addressed as a future work. There is a need to restructure the review format, which is taken up as a continuation of this work for the next batch of students.

The comparison done on the various types of assignments given to students like the written assignments, video assignments and the project assignments with around 12 attributes brings out certain interesting and relevant points for discussion. Written assignments are the best for memory retention, content learning and written expression improvement. There is always a hue and cry for written assignments that the students copy. Nevertheless, it still has an impact on the improvement of learning ability of the student.

Video assignments are very good for the present digital age students, who have craze for the usage of digital gadgets. They do show lots of excitement in doing the activity assigned. Their presentation skills improve which is evident from the feedback obtained. Due focus should be given to coding skills of each individual in the batch during the assessment of the assignments of the students. Another point which is noteworthy to mention here is since the students had just completed their freshman engineering (First year) and entered into the department level such assignments allow the students to interact with each other and also build a good foundation to face the interviews. This is the tangential benefit of the assignment given to the students in ECC230 (Data structures using $\mathrm{C}$ ).

Project assignments are having maximum impact on the learning ability of the students which is evident from the Table. 2. Proper planning is required for the assignments at the department level to see that the students are benefitted from the assignments and not burdened by the workload.

\section{Conclusions and Outcomes Achieved}

The respondents' reflections play an important role in deciding whether the assignments are useful or not useful. It is evident from the result analysis that the video assignment was beneficial for the students. The results varied from $92.6 \%$ to $82 \%$ for seven questions. A low score of $72 \%$ was the response for one question. This assignment has added value to the Programme Outcome to function effectively as an individual, communicate effectively on complex engineering activities and demonstrate an ability to develop a competency to identify software components of a complex system. Competency of the students is enhanced through this assignment. 
As a future work the investigators need to improve the course content learning ability through video assignments. It is challenging for the course instructor to device suitable instructions and assignments for the large group of 150 students which involves considerable workload.

\section{References}

[1] Chairman and Committee, "Higher education institution in a digital age: Rethinking information competency -redirecting processes," 13th General meeting of the German Rectors' conference (HRK), Nov 2012, Gottingen, Germany, 1-24

[2] Harter S, "Effectance motivation reconsidered toward a developmental model," Human Development Report, University of Denver, USA 1978, pp. 34-64.

[3] Harter S, "Manual for a scale of Intrinsic versus extrinsic orientation in classroom," A Development report, University of Denver, USA, 1980, pp 1-4.

[4] Harter S, "A new self report scale of intrinsic verses extrinsic orientation in classroom: motivational and informational components," Developmental Psychology Report 17, 1981, pp 300-312.

[5] C.K Prahalad and Gary Hamel, "The core competence of corporation," Harvard Business Review, May 1990, pp. 79-90.

[6] Robert W. White, "Motivational Reconsidered : The concept of competence," Psycholgical Review, Vol. 66(5), Sept 1959, pp. 297-333.

[7] Paul Hersey, Ken Blanchard, "Situational Leadership Theory," A Training Report of Leaderships Excellence, Feb 2009, pp. 26-30.

[8] Ryan R.M, Deu E.L, "Self determination theory and the facilitation of intrinsic motivation. Development and Well being," Journal of American Psychologist, Vol. 55, 2000, pp. 6878.

[9] Hollembeak \& A.J. Amorose, "Perceived coaching behavior and College Athletics intrinsic motivation: a test of self determination theory," Journal of Applied Psychology, Vol. 17, 2005, pp. 20-36.

[10] Berger C.R, "Message production skill in social interaction, " Journal of Greene and B.R Burleson, Handbook of Communication and Social interaction skills, Mahawah, New Jersey,
Lawrence Erlbaum Associates, Inc, 2003, pp. 257-289.

[11] Brendal J.M, Kolbert J.B, Foster V.A., "Promoting student cognitive development," Journal of Adult Development, Vol. 9, Issue 3, pp. 217-227.

[12] Burleson Brant R. "Constructivism: A General theory of communication skill," Editors Bryan Whaley, Erlbaum Lawrence and Wendy Samter, Contemporary theories and Exemplars, 2007, pp.105-128

[13] Wyer R.S Jr, Adaval R, "Message reception skills in social communication," Journal of Greene and Burleson, 2003, pp. 291-355.

[14] Wayne A. Davis, "Conceptualistic theory of knowledge," Journal of ACTA Analytica, Spring Publication, Vol. 20, Issue 1, Mar 2005, pp. 29-42.

[15] Jonassen D.H, "Objective verses constructivism: Do we need a new philosophical paradigm?," Journal of Education Research, Vol. 39, Issue 3, 1991, pp. 54-521.

[16] Bull G,Bull, G.Garafalo J, Harris J., "Grand challenges : preparing for the technological tipping point," Journal of Learning and Leading with Technology, Vol. 29, Issue 8, pp. 6-12.

[17] Hofer M, Owings Swan k, "Digital moviemaking. The harmonization of technology, pedagogy and context," International Journal of Technology in Teaching and Learning, Vol. 1, Issue 2, 2005, pp.102-110.

[18] Frand J., "The information age mindset: Changes in students Implications for Higher Education," Journal of Educase, Vol. 35, Issue 5, 2000, pp. 1419-1425.

[19] Lambert C., "Professor Video," Harvard Magazine, 2009, Issue 11, 2009, pp. 18-20.

[20] Levin D., Arafeh S., "The digital disconnect: The widening gap between interest savvy students and their schools," Research Report, Pew Research Center, Washington D.C, 2002.

[21] Tapscott D., "Growing up digital: The rise of the net generation," New York, Mc Graw Hill Publisher, 1998, pp. 203-205.

[22] Yerrick R ,Ross D, \& Molebash P., "Promoting equity with digital video," Journal of Learning and Leading with Technology, Vol. 31, Issue 4, pp. 1619-1630.

[23] Henry Greene and Cheryl Crespi, "The value of student created videos in the College Class room 
- An Exploratory study in marketing and accounting," International Journal of Arts and Science, Vol. 5, Issue 1, 2012, pp. 273-283.

[24] Raju U.S.N., Kadambari k V, Venkata Subba Redd P., "A new method of assessing the students using video assignments," Global Engineering Education Conference (EDUCON), Mar 2015, pp.1-6.

[25] Roger Graves, Anne Parker and Kathyryn Macynwk "Undergraduate Writing Assignment in Engineering: Some preliminary findings," Conference on Canadian Engineering Education Association CEEA12, 2012,pp. 4-10

[26] McCroskey J.C., "Oral communication apprehension: A summary of recent research," Journal of Human Communication Research, Vol. 4, 1977, pp. 78-96.

[27] Krannich C.R., "101 secrets of highly communicative speakers, controlling fear, commanding attention," Recording, New York , 2014.

[28] Likert, R. "A Technique for the Measurement of Attitudes,". New York: Archives of Psychology, USA, 1932, pp. 1-10. 